\title{
STUDI EMPIRIS KUALITAS AUDIT INTERNAL PEMERINTAH : MELALUI BATASAN WAKTU AUDIT DAN SKEPTISME PROFESIONAL
}

\author{
Sumartono 1), Muhammad Ridhwansyah Pasolo ${ }^{2)}$, Kevin Nugraha ${ }^{3)}$ \\ 1,2,3) Universitas Yapis Papua Program Studi Akuntansi \\ Jayapura, Papua, Indonesia \\ ${ }^{1}$ Email : destyantoro80@gmail.com
}

\begin{abstract}
Abstrak
Penelitian ini bertujuan untuk menginvestigasi bukti empiris berupa variabel batasan waktu audit dan skeptisme profesional pengaruhnya terhadap kualitas audit internal pemerintah. Populasi dalam penelitian ini adalah seluruh auditor internal pemerintah yang merupakan ASN dan bekerja pada Kantor Perwakilan Badan Pengawas Keuangan dan Pembangunan (BPKP) Provinsi Papua. Pengambilan sampel dalam penelitian ini menggunakan teknik Purposive Sampling, dengan kreteria auditor yang telah mengikuti Pendidikan dan Pelatihan Jabatan Fungsional Auditor (JFA), data penelitian diperoleh menggunakan instrumen penelitian berupa kuisioner yang didistribuskan secara langsung maupun via email kepada responden yang berisi 28 item pertanyaan diukur dengan menggunakan skala likert. Metode analisis data dalam penelitian ini menggunakan regresi linier berganda. Hasil Penelitian menunjukan bukti empiris bahwa Batasan waktu audit dan Skeptisme profesional secara parsial berpengaruh terhadap Kualitas audit internal pemerintah. Kontribusi dari hasil penelitian ini dapat memperoleh bukti empiris mengenai faktor-faktor yang mempengaruhi kualitas hasil audit internal pemerintah, yang dapat memberikan informasi kepada pengambil kebijakan maupun auditor internal pemerintah sehingga dapat menjaga mutu serta meningkatkan kualitas audit internal pemerintah.
\end{abstract}

Kata Kunci : Batasan Waktu Audit, Skeptisme Profesional, Kualitas Audit Internal Pemerintah, Auditor Internal Pemerintah.

\begin{abstract}
This study aimed to investigate empirical evidence in the form of variables of audit time limit and professional skepticism in terms of their influence on the quality of the Government's internal audit. The population in this study were all the Government internal auditors who are members of State Civil Apparatus (ASN) and work at the Representative Office of the Papua Province's Financial and Development Supervisory Agency (BPKP). The study used purposive sampling technique, with the criteria of auditors who had followed the Education and Training of Functional Role of Auditors (JFA). The research data were obtained using research instruments in the form of questionnaires containing 28 question items distributed directly or via email to respondents and measured by using Likert scale. The method in this study used multiple linear regression. The results showed empirical evidence that the audit time limit and professional skepticism partially affected the quality of the Government's internal audit. The contributions of this study are that it is able to obtain empirical evidence about the factors that influence the quality of the Government's internal audit results, which can provide information to policy makers and internal auditors of the Government, so that it can be of quality and improve the quality of the Government's internal audit.
\end{abstract}

Keywords : Audit time limit, Professional Skepticism, Government's Internal Audit Quality, Government's Internal Auditors 


\section{LATAR BELAKANG}

Transparansi dan akuntabilitas keuangan publik merupakan unsur penting dalam terciptanya tata kelola pemerintah yang baik (Sumartono \& Pasolo, 2019), namun ada tiga 3 aspek utama lainnya yang mendukung terciptanya pemerintahan yang baik (good governance) sebagai wujud dari pertanggungjawaban Pemerintah kepada masyarakat dalam mengelola keuangan negara, sebagaimana peraturan menteri pendayagunaan Aparatur Negera (PERMENPAN) Nomor 19 Tahun 2009 tentang Pedoman Kenadali Mutu Audit Aparat Pengawasan Intern Pemerintah (APIP), yaitu pengawasan, pengendalian, dan pemeriksaan (Darmawati \& Dewi, 2018).

Salah satu Aparat Pengawas Intern Pemerintah (APIP) pemerintah yang mempunyai tugas pokok dan fungsi melakukan pengawasan adalah Badan Pegawasan Keuangan dan Pembangunan (BPKP), Auditor pemerintah yang berada di instansi BPKP, mereka dituntut untuk menaati kode etik Aparat Pengawasan Intern Pemerintah (APIP) serta standar audit APIP atau standar audit lainnya yang telah ditetapkan. Dengan adanya Kode Etik APIP dan Standar Audit APIP masih saja menimbulkan banyak persoalan berupa praktik-praktik kecurangan berupa adanya kasus korupsi maupun penyelewengan. Persolan ini akan berdampak pada komitmen auditor internal pemerintah terhadap kode etik dan standar audit agar mutu hasil audit intern yang dilakukan terhadap kualitas audit dapat terjaga dan ditingkatkan.

Menurut AAIPI, (2013) Untuk menjaga mutu hasil audit intern yang dilaksanakan oleh Auditor Intern Pemerintah, perlu disusun Standar Audit Intern Pemerintah Indonesia. Standar Audit Intern Pemerintah Indonesia, adalah kreteria atau ukuran mutu minimal untuk melakukan kegiatan audit intern yang wajib dipedomani oleh auditor dan Pimpiman APIP. Standar Audit dimaksudkan agar pelaksanaan audit intern berkualitas.
Ada beberapa faktor yang mempengaruhi kualitas audit, yaitu hal yang sering menjadi perhatian tim audit adalah faktor keterbatasan waktu yang dialokasikan oleh entitas audit kepada tim dalam melaksanakan tugasnya. Sehingga dengan alokasi waktu yang terbatas dapat berimbas pada keakuratan dalam penyajian laporan audit. dan hampir dari sejumlah penugasan yang ditangani oleh auditor rata-rata dapat menambah tingkat tekanan waktu yang dirasakan yang pada akhirnya dapat berdampak pada kualitas audit (Svanström, 2016).

Hastuti, (2013) mengungkapkan bahwa tekanan anggaran waktu yang dirasakan berhubungan positif signifikan dengan perilaku audit disfungsional, yang mengindikasikan semakin tinggi tekanan anggaran waktu yang dirasakan auditor, maka semakin meningkat pula kecenderungan mereka melakukan tindakan audit disfungsional, yaitu perilaku penurunan kualitas audit dalam pelaksanaan program audit. Lain halnya dengan Rustiarini, (2013) yang mengungkapkan bahwa tekanan waktu tidak berpengaruh pada kinerja auditor, dimana auditor semestinya dituntut untuk dapat bekerja seefesien mungkin sesuai anggaran waktu yang ditentukan.

Faktor selanjutnya adalah Skeptisme profesional (Kalau, 2013); (Ardian, 2013). Sanjaya, (2017) mengatakan bahwa Sikap skeptisisme profesional auditor adalah sikap kritis yang selalu mempertanyakan keandalan bukti audit atau informasi yang diperoleh dari pihak klien. Oleh karena itu untuk menerapkan skeptisme professional yang efektif, perlu dibentuk persepsi bahwa sistem pengendalian internal yang paling baik pun akan mempunyai celah, dan memungkinkan terjadinya fraud.

Penelitian terkait dengan kualitas audit internal pemerintah masih relatip kurang dibandingkan dengan audit sektor privat diantaranya peneliti (Taman, Putra, \& Rachmawati, 2018); Wijayanto \& Mustikawati, (2017); (Bachtiar, 2017); (Yulia, Hasan, \& Hardi, 2016); (Wiratama, 2015); (Susilawati \& Atmawinata, 2014); 
Sumartono, MR Pasolo \& Kevin N, Studi Empiris Kualitas Audit Internal Pemerintah...

dan (Kalau, 2013); berdasarkan Paparan diatas dan dari penelitian yang telah dilakukan sebelumnya, maka dalam penelitian ini, peneliti berusaha melakukan penelitian fokus pada sektor publik di Indonesia dengan mengindentifikasi 2 faktor/variabel potensial yang diprediksi mempengaruhi kualitas hasil audit, yaitu Batasan waktu audit dan Skeptisme profesiona dan ada pun tujuan dari penelitian ini adalah untuk menginvestigasi bukti empiris berupa variabel batasan waktu audit dan skeptisme profesional pengaruhnya terhadap kualitas audit internal pemerintah.

\section{TINJAUAN PUSTAKA DAN PENGEMBANGAN HIPOTESIS AUDIT}

Audit adalah akumulasi dan evaluasi bukti tentang informasi untuk menentukan dan melaporkan tingkat kesesuaian antara informasi dan kriteria yang telah ditetapkan. Audit harus dilakukan oleh seorang yang kompeten dan independen (Arens, Elder, Beasley, \& Hogan, 2017). Sedangkan Messier, Glover, \& Prawitt, (2016) Mendefinisikan audit sebagai suatu proses yang sistemastis secara objektif guna meperoleh dan mengevaluasi bukti tentang pernyataan tentang tindakan dan peristiwa ekonomi untuk dipastikan tingkat kesesuaian antara pernyataan dan menetapkan kreteria serta mengkomunikasikan hasilnya bagi pengguna yang tertarik. Sedangkan Mulyadi, (2014) mendefinisikan audit sebagai suatu proses sistemik untuk memperoleh dan mengevaluasi bukti secara objektif mengenai pernyataan-pernyataan tentang kegiatan dan kejadian ekonomi dengan tujuan untuk menetapkan tingkat kesesuaian antara pernyataan-pernyataan tersebut dengan kriteria yang telah ditetapkan, serta penyampaian hasil-hasilnya kepada pemakai yang berkepentingan.

Definisi yang terdapat dalam Standar Audit Intern Pemerintah Indonesia (SAIPI) yakni audit adalah proses identifikasi masalah, analisis, dan evaluasi yang dilakukan secara independen, objektif, dan profesional berdasarkan standar audit, untuk menilai kebenaran, kecermatan, kredibilitas, efektivitas, efisiensi, dan keandalan informasi pelaksanaan tugas dan fungsi instansi pemerintah.

Dengan demikian dari paparan diatas dapat disimpulkan bahwa audit memiliki karakteristik sebagai berikut; (1) proses pengumpulan dan pengevaluasian bukti, (2) dilakukan oleh orang yang kompeten dan independen, (3) penentuan kesesuaian antara kriteria dan bukti (informasi), (4) pelaporan kepada pihak yang berkepentingan.

\section{Kualitas Hasil Audit}

Tidak mudah untuk menggambarkan dan mengukur kualitas audit secara obyektif dengan beberapa indikator. Hal ini dikarenakan kualitas audit merupakan sebuah konsep yang kompleks dan sulit dipahami, sehingga sering kali terdapat kesalahan dalam menentukan sifat dan kualitasnya. Hal ini terbukti dari banyaknya penelitian yang menggunakan dimensi kualitas audit yang berbeda - beda. DeAngelo, (1981) mendefinisikan kualitas audit sebagai probabilitas bahwa auditor akan menemukan dan melaporkan pelanggaran pada sistem akuntansi auditee. Sedangkan Giroux \& Jones, (2011) menjelaskan bahwa probabilitas untuk menemukan pelanggaran tergantung pada kemampuan teknis auditor dan probabilitas melaporkan pelanggaran tergantung pada independensi auditor.

Menurut Marxen (1990) dalam Hari, Rasuli, \& Darlis, (2015) menyatakan bahwa buruknya kualitas audit disebabkan oleh beberapa perilaku disfungsional, yaitu: Underreporting of time, premature sign off,altering/ replacement of audit procedure. Underreporting of time menyebabkankeputusan personil yang kurang baik, menutupi keputusan revisi anggaran, dan menghasilkan time pressure untuk audit di masa datang yang tidak diketahui. Premature sign - off (PMSO) merupakan suatu keadaan yang menunjukkan auditor menghentikan satu atau beberapa langkah audit yang diperlukan dalam prosedur audit tanpa menggantikan dengan langkah yang lain. Sedangkan altering/ replacement of 
audit procedure adalah penggantian prosedur audit yang seharusnya yang telah ditetapkan dalam standar auditing. Sehingga audit yang berkualitas adalah audit yang dapat ditindaklanjuti oleh auditee. Kualitas ini harus dibangun sejak awal pelaksanaan audit hingga pelaporan dan pemberian rekomendasi (Efendy, 2010).

\section{Batasan Waktu Audit}

Dalam SPAP (SA Seksi 326, PSA No 07) disebutkan bahwa auditor bekerja dalam batas-batas pertimbangan ekonomi agar secara ekonomis bermanfaat, pendapatnya harus dirumuskan dalam jangka waktu yang masuk akal. Auditor harus berani memutuskan, dengan menggunakan pertimbangan profesionalnya, apakah bukti audit yang tersedia yang diperoleh dengan batasan waktu yang cukup memadai untuk membenarkan dan menyakinkan pernyataan pendapatnya. Auditor harus menetapkan alokasi waktu audit yang cukup dan sangat ketat, akan tetapi akibatnya memiliki efek yang merugikan publik, yaitu memunculkan perilaku yang akan mengancam kualitas audit itu sendiri, dianataranya penurunan tingkat pendeteksian dan penyelidikan aspek kualitatif salah saji yang dilakukaanya, gagal dalam meneliti prinsip akuntansi, melakukan review dokumen secara dangkal dan asalasalan, lemahnya menerima penjelasan dari klien dan mengurangi beban pekerjaan pada salah satu proses audit di bawah tingkat yang diterimanya.

Di bawah tekanan-tekanan waktu, perhatian akan lebih terfokus pada tugas yang dominan seperti tugas pengumpulan bukti berkaitan dengan frekuensi dan jumlah salah saji dan mengorbankan perhatian yang diberikan pada tugas tambahan seperti tugas yang memberikan aspek kualitatif atas terjadinya salah saji yang menunjukkan potensial kecurangan pelaporan keuangan.

Jadi penetapan waktu untuk auditor dalam melaksanakan tugasnya harus tepat waktu, sehingga hal-hal seperti disebutkan pada uraian diatas dapat dihindari. Hal ini juga akan dapat mempengaruhi tingkat kepercayaanmasyarakat terhadap kualitas auditor.

\section{Skeptisme Profesional}

Dalam Standar Profesional Akuntan Publik (SPAP) ,Standar Audit (SA) paragraf 13 huruf 1, Skeptisisme professional adalah suatu sikap yang mencakup suatu pikiran yang selalu mempertanyakan, waspada terhadap kondisi yang dapat mengindikasikan kemungkinan kesalahan penyajian, baik yang disebabkan oleh kecurangan maupun kesalahan, dan suatu penilaian penting atas bukti audit. Skeptisisme profesional mencakup kewaspadaan terhadap hal-hal berikut ini:

a. Bukti audit yang bertentangan dengan bukti audit lain yang diperoleh.

b. Keadaan yang mengindikasikan adanya kemungkinan kecurangan.

c. Kondisi yang menyarankan perlunya prosedur yang disyaratkan oleh SA (Standar Audit).

d. Informasi yang menimbulkan pertanyaan tentang keandalan dokumen dan tanggapan terhadap permintaan keterangan yang digunakan sebagai bukti audit.

Dalam Standar Profesional Akuntan Publik (2011) menjelaskan bahwa skeptisisme profesional adalah sikap yang selalu mempertanyakan dan melakukan evaluasi bukti audit secara kritis. Pengertian serupa dipaparkan dalam International Standards on Auditing (IAASB, 2009), skeptisisme profesional adalah sikap yang meliputi pikiran yang selalu bertanyatanya (questioning mind), waspada (alert) terhadap kondisi dan keadaan yang mengindikasikan adanya kemungkinan salah saji material yang disebabkan oleh kesalahan atau kesengajaan (fraud), dan penilaian (assessment) buktibukti audit secara kritis. Konsep skeptisisme profesional yang tercermin dalam standar tersebut adalah sikap selalu bertanya-tanya, waspada, dan kritis dalam melaksanakan seluruh proses audit. 
Sumartono, MR Pasolo \& Kevin N, Studi Empiris Kualitas Audit Internal Pemerintah...

HIPOTESIS PENELITIAN

PENGARUH BATASAN WAKTU AUDIT TERHADAP KUALITAS AUDIT INTERNAL PEMERINTAH.

Batasan waktu audit merupakan batasan waktu yang diberikan kepada auditordalam melakukan pemeriksaan terhadap suatu instansi atau perusahaan (Maulina, Darwanis, \& Saputra, 2017). Sehingga di bawah tekanan waktu, perhatian auditor akan lebih fokus pada tugas yang dominan seperti tugas pengumpulan bukti berkaitan dengan frekuensi dan jumlah salah saji dan mengorbankan perhatian yang diberikan pada tugas tambahan seperti tugas yang memberikan aspek kualitatif atas terjadinya salah saji material yang menunjukkan potensial kecurangan pada pelaporan keuangan.

Waktu audit yang terbatas menjadi tantangan tersendiri bagi auditor mengingat tuntutan untuk menghasilkan laporan yang berkualitas. Dalam setiap audit, Pemerintah perlu untuk membuat anggaran belanja waktu pusat maupun daerah yang relevan bagi auditor sesuai dengan karakteristik masingmasing daerah. Anggaran waktu diperlukan untuk menentukan cost audit dan untuk mengukur efektifitas dari kinerja auditor. Anggaran waktu yang tidak realistis dengan pekerjaan yang dilakukan akan menyebabkan munculnya perilaku-perilaku non etis yang berdampak pada rendahnya kualitas dari audit itu sendiri (Purwaningsih, 2018).

Maulina et al., (2017) menunjukkan bahwa batasan waktu audit bepengaruh terhadap kualitas audit. Bedasarkan paparan diatas, dapat disimpulkan hipotesis sebagai berikut :

\section{$H_{1}$ : Skeptisme Batasan Waktu Audit terhadap Kualitas audit internal pemerintah.}

Pengaruh Skeptisme Profesional terhadap Kualitas Audit Internal Pemerintah.

Skeptisme profesional auditor merupakan sikap auditor yang mencakup pikiran yang selalu mempertanyakan dan melakukan evaluasi secara kritis terhadap bukti audit (AAIPI, 2013). Penggunaan kemahiran profesional dengan cermat dan seksama menuntut auditor untuk melaksanakan skeptisisme profesional. Dapat diartikan bahwa skeptisisme profesional menjadi salah satu faktor dalam menentukan kemahiran profesional seorang auditor. Kemahiran profesional akan sangat mempengaruhi ketepatan output hasil audit yang telah dilakukan. Dengan demikian dapat dikatakan bahwa semakin tinggi tingkat skeptisme seorang auditor dalam melakukan audit, maka di akan berpengaruh pada hasil kualitas audit tersebut (Turangan, Saerang, \& Sondakh, 2016).

Koop, Lemon, \& Rennie, (2003) Mengatakan bahwa ketidakmampuan auditor dalam menerapkan skeptisisme profesional selama proses audit akan mengganggu kualitas audit. Sebagaimana halnya Kalau, (2013) dan Afriyani, Anugerah, \& Rofika, (2014) yang menunjukan adanya pengaruh signifikan antara skeptisisme profesional terhadap kualitas hasil audit. Bedasarkan paparan diatas, dapat disimpulkan hipotesis sebagai berikut :

\section{$\mathrm{H}_{2}$ : Skeptisme Profesional bepengaruh terhadap Kualitas audit internal pemerintah.}

\section{METODE PENELITIAN \\ Populasi dan Sampel}

Populasi dalam penelitian ini adalah auditor internal pemerintah yang merupakan Aparatur Sipil Negara (ASN) yang bekerja pada Kantor Perwakilan BPKP Provinsi Papua. Sampel dipilih berdasarkan metode purposive sampling dengan tujuan untuk mendapatkan sampel yang representif sesuai dengan kriteria yang di tentukan. Menurut Sugiyono, (2014); Chandarin, (2018) Purposive sampling merupakan metode penentuan sampel dengan berdasar pada pertimbangan atau kreteria tertentu. pertimbangan yang ditentukan oleh peneliti dalam pengambilan sampel pada penelitian ini adalah auditor pemerintah yang telah mengikuti pendidikan dan pelatihan JFA (Jabatan Fungsional Auditor). 
Data yang dipergunakan dalam penelitian ini menggunakan data Primer, melalui metode pengumpulan data menggunakan instrumen penelitian berupa kuesioner untuk dijawab dikirimkan keresponden secara langsung. Pengukuran Instrumen dalam penelitian ini menggunakan 5 (lima) poin skala Likert. diberi skor sebagai berikut : Skor 1 = Sangat tidak setuju, Skor 2 $=$ Tidak setuju, Skor $3=$ Netral atau raguragu, Skor $4=$ Setuju, dan Skor $5=$ Sangat setuju.

\section{Definisi Operasional Variabel Penelitian Variabel Dependen}

Variabel Dependen dalam penelitian ini adalah kualitas audit pemerintah menggunakan indikator kesesuaian pemeriksaan dengan standar audit, perencanaan audit dan kertas kerja audit, dan kualitas laporan dan tindak lanjut hasil pemeriksaan yang diadopsi dari Sukriah dkk, (2009) dalam (Syarif, 2017). Dalam penelitian ini mengunakan 10 item pernyataan.

\section{Variabel Independen}

Batasan waktu audit adalah kondisi di mana auditor mendapatkan tekanan dari tempatnya bekerja untuk dapat menyelesaikan tugasnya sesuai dengan waktu yang telah ditetapkan. Indikator tekanan batasan waktu berupa; ketepatan waktu, pencapaian anggaran waktu, keterbatasan sumber daya, tingkat efisiensi terhadap anggaran waktu, dan kepatuhan auditor (Nataline, 2007). Dalam penelitian ini menggunakan 9 item pernyataan.

Skeptisme profesional adalah sikap yang mencakup pikiran yang selalu mempertanyakan dan melakukan pengujian secara kritis terhadap bukti (AAIPI, 2013). Pengumpulan dan pengujian bukti secara objektif menuntut Auditor selalu

mempertimbangkan

relevansi, kompetensi, dan kecukupan bukti. Oleh karena bukti dikumpulkan dan diuji selama proses kegiatan audit intern berlangsung, sehingga sikap skeptisme profesional harus digunakan selama proses pengumpulan bukti tersebut tersebut. dalam penelitian ini variabel Skeptisme di ukur dengan indikator yang dikembangkan dari Suraida, (2005), yaitu pikiran yang selalu mempertanyakan bukti audit, tingkat keraguan auditor terhadap bukti audit, melakukan audit tambahan dan konfirmasi langsung, dengan menggunakan 9 item pernyataan.

\section{HASIL DAN DISKUSI \\ Test Instrumen Penelitian}

Sebelum kuesioner yang merupakan instrumen dalam penelitian digunakan secara luas terlebih dahulu dilakukan uji coba terlebih dahulu terhadap 30 responden untuk mengukur realibilitas dan validitas dari alat ukur tersebut.

\section{Uji Validitas}

Pengujian Validitas ini dilakukan untuk mengetahui apakah semua item-item pernyataan dari kontruks dalam penelitian ini yang dirumuskan dalam instrumen penelitian berupa kuesioner sebagai alat ukur variabel adalah valid. Validitas (validity) menunjukan seberapa jauh suatu tes atau set dari operasi operasi mengukur apa yang seharusnya diukur (Ghiselli, Campbell, \& Zedeck, 1981). Hartono, (2013) menyatakan bahwa validitas menunjukan seberapa nyata suatu pengujian mengukur apa yang seharusnya diukur. Instrumen yang valid berarti alat ukur yang digunakan untuk mendapatkan data (mengukur) itu valid (Sugiyono, 2014).

Pengujian validitas dilakukan dengan menggunakan alat bantu sofware program statistik, dengan kriteria sebagai berikut : Jika $r$ hitung positif atau $r$ hitung $>r$ tabel, maka item pernyataan tersebut valid; Jika $r$ hitung negatif atau $r$ hitung $<r$ tabel, maka item pernyataan tersebut tidak valid. Untuk mencari Nilai $r$ tabel dapat diperoleh melalui df $($ degree of freedom $)=n-2$. Dimana $n=$ jumlah sampel penelitian, Sehingga hasil uji validitas pada instrumen penelitian ini dengan menggunkaan taraf signifikansi 5\%, yaitu df $=89-2=87$ sehingga diperoleh nilai $\mathrm{r}$ tabel 0.208 Sehingga hasil Uji Validitas masing-masing variabel dapat dilihat pada tabel 1 . 
Sumartono, MR Pasolo \& Kevin N, Studi Empiris Kualitas Audit Internal Pemerintah...

Tabel 1 Hasil Uji Validitas

\begin{tabular}{ccccc}
\hline Variabel & $\begin{array}{c}\text { Item } \\
\text { Pernyataan }\end{array}$ & $\mathbf{r}$ hitung & $\mathbf{r}_{\text {tabel }}$ & Ket \\
\hline & 1 & 0,901 & 0,208 & Valid \\
Batasan & 2 & 0,885 & 0,208 & Valid \\
Waktu & 4 & 0,858 & 0,208 & Valid \\
Audit & 5 & 0,854 & 0,208 & Valid \\
& 6 & 0,782 & 0,208 & Valid \\
& 7 & 0,784 & 0,208 & Valid \\
& 8 & 0,716 & 0,208 & Valid \\
& 9 & 0,828 & 0,208 & Valid \\
& & & & Valid \\
\hline
\end{tabular}

\begin{tabular}{ccccc}
\hline Variabel & $\begin{array}{c}\text { Item } \\
\text { Pernyataan }\end{array}$ & $\mathbf{r}$ hitung & $\mathbf{r}$ tabel & Ket \\
\hline & 1 & 0,724 & 0,208 & Valid \\
& 2 & 0,814 & 0,208 & Valid \\
Skeptisme & 3 & 0,744 & 0,208 & Valid \\
Profesional & 4 & 0,734 & 0,208 & Valid \\
& 5 & 0,734 & 0,208 & Valid \\
& 6 & 0,793 & 0,208 & Valid \\
& 7 & 0,841 & 0,208 & Valid \\
& 9 & 0,853 & 0,208 & Valid \\
& 9 & 0,834 & 0,208 & Valid \\
\hline Kualitas & 1 & 0,652 & 0,208 & Valid \\
Audit Internal & 2 & 0,803 & 0,208 & Valid \\
Pemerintah & 3 & 0,778 & 0,208 & Valid \\
& 5 & 0,784 & 0,208 & Valid \\
& 7 & 0,771 & 0,208 & Valid \\
& 8 & 0,695 & 0,208 & Valid \\
& 9 & 0,775 & 0,208 & Valid \\
& 10 & 0,714 & 0,208 & Valid \\
& 0,818 & 0,208 & Valid \\
& 10,208 & Valid \\
\hline
\end{tabular}

Tabel 1 menunjukkan bahwa seluruh item pernyataan dari masing-masing kontruk valid, karena dibuktikan dengan hasil $\mathrm{r}$ hitung bernilai positif atau $r$ hitung $>r$ tabel. Dengan demikian dapat dilanjutkan ketahap selanjutnya yaitu uji reliabilitas.

\section{Uji Reliabilitas}

Reliabilitas menunjukan akurasi dan ketepatan dari pengukurannya yang berhubungan dengan akurasi dan konsistensi. Dikatakatan reliabel (dapat diandalkan) pengukuran harus akurat dan konsisten sehingga jika dilakukan beberapa pengukuran terhadap subjek yang sama maka diperoleh hasil yang tidak berbeda atau jika jawaban seseorang terhadap pernyataan adalah konsisten dari waktu ke waktu (Indriantoro \& Supomo, 2002); (Ghozali, 2016).

Cara mengukur reliabilitas dalam penelitian ini menggunakan koefisien alpha Cronbach. Dengan kreteria bahwa suatu konstruk/variabel dikatakan reliabel jika nilai Cronbach Alpha > 0,7 (Nunnally, 1967). Hasil dari uji reliabilitas masing-masing variabel pada penelitian ini dapat dilihat pada tabel 2.

Tabel 2 Hasil Uji Reliabilitas

\begin{tabular}{llcl}
\hline No. & \multicolumn{1}{c}{ Variabel } & $\begin{array}{c}\text { Cronbach's } \\
\text { Alpha }\end{array}$ & Ket. \\
& & & \\
\hline 1. & Batasan Waktu Audit & 0,938 & Reliabel \\
2. & Skeptisme Profesional & 0,921 & Reliabel \\
3. & Kualitas Audit Internal & 0,914 & Reliabel \\
& Pemerintah & & \\
\hline
\end{tabular}

Berdasarkan tabel 2, menunjukan bahwa seluruh item pernyataan pada setiap variabel penelitian dinyatakan reliabel, karena memiliki nilai Cronbach's Alpha > 0,7 .

Sebelum melakukan pengujian hipotesis dengan menggunakan analisis regresi, maka diperlukan pengujian asumsi klasik yang meliputi pengujian : (a) normalitas, (b) multikolinearitas, dan (c) heterokedastisitas.

Uji normalitas data dalam penelitian ini dengan uji Kolmogorov-Smirnov dengan dasar keputusan : Nilai sig. atau signifikan atau probabilitas $<0,05$, maka distribusi data adalah tidak normal, dan jika Nilai sig. atau signifikan atau probabilitas > 0,05, maka distribusi data adalah normal.

Adapun hasil dari uji normalitas data uji Kolmogorov-Smirnov dapat dilihat pada tabel 3.

Tabel 3 Uji Normalitas Data Kolmogorov-Smirnov test

\begin{tabular}{lr}
\hline & Unstandardized Residual \\
\hline $\mathrm{N}$ & 89 \\
Asymp. Sig. (2-tailed) & $200^{\mathrm{c}, \mathrm{d}}$ \\
\hline
\end{tabular}

Berdasarkan hasil pengujian normalitas data pada tabel 5.15, menunjukan bahwa nilai Sig. (2-tailed) 0,200 >0,05, sehingga dipastikan data penelitian ini berdistribusi normal.

Uji Multikolinieritas data penelitian ini menggunakan dasar pengambilan keputusan dengan melihat nilai Tolerance dan Nilai VIF, Jika nilai tolerance > 0,1 , maka tidak terjadi Multikolinieritas, dan Jika nilai tolerance $<0,1$, maka terjadi Multikolinieritas. Kemudian Jika nilai VIF < 10, maka tidak terjadi Multikolinieritas, dan Jika nilai VIF $>=10$, maka terjadi 
Journal of Business Administration Vol 3, No 2, September 2019, hlm, 245-257

Multikolinieritas. Adapun hasil dari uji Multikolinieritas data disajikan pada tabel 4.

Tabel 4 Uji Multikolinearitas

\begin{tabular}{lcc}
\hline \multirow{2}{*}{ Model } & \multicolumn{2}{c}{ Collinearity Statistics } \\
\cline { 2 - 3 } & Tolerance & VIF \\
\hline (Constant) & & \\
Batasan Waktu Audit &, 156 & 6,414 \\
Skpetisme Profesional &, 156 & 6,414 \\
\hline
\end{tabular}

Dari tabel 4, dapat dilihat bahwa nilai $V I F$ dari setiap variabel independen tidak ada yang lebih dari 10 dan nilai tolerance tidak ada yang kurang dari 0,1 , maka dapat disimpulkan bawa tidak terjadi multikolinieritas dalam model regresi dalam penelitian ini. Adapun hasil dari Uji Heteroskedastisitas menggunakan bantuan sofware SPSS Ver.25 disajikan pada gambar 1.

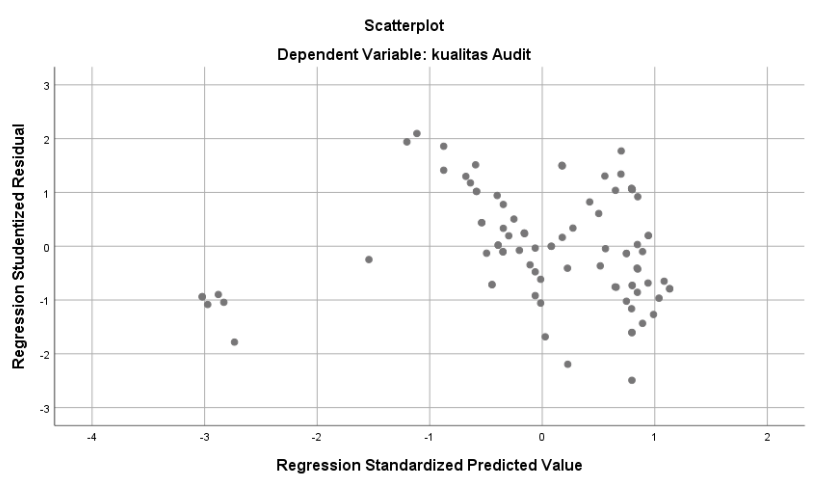

Gambar 1 Scatterplot Uji Heteroskedastisitas

Berdasarkan Gambar 1, terlihat bahwa titik-titik menyebar secara acak tidak membentuk suatu pola tertentu dan tersebar baik di atas maupun dibawah angka nol pada sumbu Y. Hal ini menunjukkan bahwa tidak terjadi heteroskedastisitas pada model regresi, dengan demikian dapat disimpulkan model regresi layak digunakan.

\section{Uji Hipotesis dan Pembahasan}

Uji-t dilakukan untuk menganalisis pengaruh suatu variabel independen yaitu Batasan waktu audit, dan Skeptisme profesional terhadap variabel dependen yaitu Kualitas audit internal pemerintah. Pengujian ini juga dimaksudkan untuk mengetahui variabel independen mana yang lebih dominan mempengaruhi variabel dependen.
Dengan kreteria penentuan hasil pengujian dilakukan dengan membandingkan nilai thitung dengan $t_{\text {tabel }}$ atau melihat tingkat signifikansinya atau nilai pvalue dengan ketentuan bahwa jika nilai pvalue $<0,05$, maka berpengaruh (Ha diterima dan $\mathrm{Ho}$ ditolak) dan Jika nilai pvalue $>0,05$, maka tidak berpengaruh (Ha ditolak dan Ho diterima). hasil olah data uji-t disajikan pada tabel 5.

Tabel 5. Hasil Analisis Regresi Linier Berganda

\begin{tabular}{lcccc}
\hline \multicolumn{1}{c}{ Variabel } & $\begin{array}{c}\text { Koefisisen } \\
(\boldsymbol{\beta})\end{array}$ & $\mathbf{t}_{\text {hitung }}$ & $\boldsymbol{P}_{\text {Value }}$ & Ket \\
\hline Batasan Waktu Audit & 0,609 & 7,077 & 0,000 & + \\
Skeptisme Profesional & 0,314 & 3,612 & 0,001 & + \\
Konstanta $(\alpha)$ & 7,242 & 5,515 & 0,000 & \\
Adj $R$ Square & & & & 0,889 \\
$\mathrm{~N}$ & & & & 89 \\
\hline
\end{tabular}

Berdasarkan tabel 1, 2 variabel yaitu Batasan waktu audit dan skeptisme profesional memiliki pengaruh positif terhadap kualitas audit internal pemerintah sehingga semakin tinggi skeptisme profesional auditor internal pemerintah, dan skeptisme profesional, maka akan meningkatkan kualitas audit internal pemerintah.

Dari hasil analisis pada tabel 5, dapat diketahui bahwa koefisien determinasi (adjusted $R^{2}$ ) yang diperoleh sebesar 0,889 . Hal ini berarti bahwa variabel Batasan waktu audit $\left(\mathrm{X}_{1}\right)$, dan Skeptisme Profesional $\left(\mathrm{X}_{2}\right)$, pengaruh sebesar 88,9 terhadap variabel Kualitas audit internal pemerintah (Y). Sedangkan sisanya sebesar $11,1 \%$ dipengaruhi oleh faktor lain diluar penelitian ini.

Pembahasan dari hasil analisis regresi linier berganda dapat ditunjukan dibawah ini

\section{Pengaruh Batasan Waktu Audit terhadap Kualitas Audit Internal Pemerintah.}

Hasil uji t dari tabel 5.17 menyatakan, untuk variabel Batasan Waktu Audit $\left(\mathrm{X}_{1}\right)$ diperoleh $t_{\text {hitung }}$ sebesar 7,077 dan $t_{\text {tabel }}$ sebesar 1,987 dengan ketentuan $(\mathrm{n}-\mathrm{k}=89$ 3 = 86), sedangkan Pvalue sebesar 0,000 dibawah nilai $\alpha=0,05$. Sehingga diperoleh nilai $t_{\text {hitung }} 7,077>t_{\text {tabel }} 1,987$, yang berarti bahwa Ha diterima dan Ho ditolak. 
Sumartono, MR Pasolo \& Kevin N, Studi Empiris Kualitas Audit Internal Pemerintah...

Dalam temuan empiris menunjukkan bahwa batasan waktu audit mampu meningkatkan Kualitas hasil audit. artinya bahwa dengan Batasan waktu yang cukup dan tidak mengalami tekakan maka berdampak pada Kualitas hasil audit yang dilakukan oleh auditor.

Dalam penugasan audit, auditor pemerintah biasanya sudah memiliki data awal tentang auditee karena klien dari auditor pemerintah adalah kementerian/lembaga yang setiap tahunnya di audit, auditor tidak perlu lagi mempelajari karakteristik bisnis proses klien, karena auditor telah mempelajari perusahaan klien saat dia melakukan penugasan pertama kali sehingga pada saat melakukan audit di lapangan, auditor langsung melakukan verifikasi data dan melakukan prosedur audit yang telah ditetapkan. Kadang penetapan batasan waktu tidak realistis pada tugas audit, sehingga apabila penetapan batasan waktu terlalu lama hal ini akan berdampak negatif pada tingginya biaya dan efektivitas pelaksanaan audit sehingga akan berdampak pada kualitas audit. Hasil penelitian ini didukung oleh Maulina et al., (2017) dan Hastuti, (2013), yang menunjukkan bahwa Batasan waktu audit berpengaruh positif signifikan terhadap kualitas audit, akan tetapi lain halnya dengan Purwaningsih, (2018) yang menunjukkan bahwa batasan waktu audit tidak berpengaruh terhadap kualitas audit.

\section{Pengaruh Skeptisme profesional terhadap Kualitas Audit Internal Pemerintah.}

Hasil uji t pada tabel 3, untuk variabel Skeptisme profesional $\left(\mathrm{X}_{2}\right)$ diperoleh $\mathrm{t}_{\text {hitung }}$ sebesar 3,612 dan $t_{\text {tabel }}$ sebesar 1,987 dengan ketentuan $(\mathrm{n}-\mathrm{k}=89-3=86$, sedangkan nilai Pvalue sebesar 0,001 dibawah nilai $\alpha=$ 0,05 . sehingga diperoleh nilai $t_{\text {hitung }} 3,612>$ $t_{\text {tabel }} 1,987$, yang berarti bahwa Ha diterima dan Ho ditolak. Sehingga dapat disimpulkan bahwa Skeptisme profesional secara parsial bepengaruh terhadap kualitas audit internal pemerintah.

Menurut AAIPI, (2013) Skeptisme profesional adalah sikap yang mencakup pikiran yang selalu mempertanyakan dan melakukan pengujian secara kritis terhadap bukti audit yang diperoleh. Pengumpulan dan pengujian bukti secara objektif menuntut Auditor mempertimbangkan relevansi, kompetensi, dan kecukupan bukti tersebut. Oleh karena bukti dikumpulkan dan diuji selama proses kegiatan audit intern,sehingga sikap skeptisme profesional harus digunakan selama proses audit berlangsung. Hal ini tidak terlepas dari pertimbangan risiko yang potensial yang akan dihadapi oleh auditor. Dengan demikian, auditor yang memiliki kewaspadaan dan memiliki sikap skeptis dalam melakukan tugasnya dapat mengungkapkan keadaan objek pemeriksa yang diauditnya secara benar dan adanya sikap tersebut akan meningkatkan kualitas audit.

Keingintahuan lebih banyak atau keraguan auditor terhadap informasi atau bukti yang diperoleh akan meningkatkan kualitas audit. Semakin tinggi tingkat skeptisisme auditor, semakin baik auditor untuk memperoleh bukti terkait dengan pemeriksaan laporan keuangan klien (Mardijuwono \& Subianto, 2018). Sehingga sikap Skeptisisme profesional auditor memiliki potensi untuk membantu auditor dalam menemukan semua bentuk pelanggaran yang dilakukan oleh klien dalam hal ini bidang pelaporan keuangan.

Berdasarkan bukti empiris dalam penelitian ini ditemukan bahwa Skeptisme Profesional berpengaruh positif terhadap Kualitas Hasil Audit, dimana peran dari sikap skeptis sangat dibutuhuan bagi seorang auditor internal pemerintah untuk tidak mudah percaya terhadap bukti maupun fakta yang ada sebagai alat pertimbangan guna memberikan sebuah penilaian guna memberikan opini terhadap hasil pemeriksaan yang telah dilakukan sehinga auditor tidak sesat dalam memberikan sebuah opini, dengan sikap skeptisme profesional auditor mampu meningkatkan hasil pemeriksaan ataupun audit yang dilakukan. Hasil penelitian ini didukung oleh (Ardian, 2013); (Anugerah \& Akbar, 2014); (Afriyani et al., 2014); (Turangan et al., 2016);(Purwaningsih, 2018) dan (Mardijuwono \& Subianto, 2018), yang 
menunjukkan bahwa bahwa skeptisme profesional berpengaruh positif signifikan terhadap Kualitas audit.

\section{KESIMPULAN}

Dari nilai adjusted $R^{2}$ koefesien determinasi penelitian ini menunjukkan nilai $88,9 \%$, yang berarti bahwa variabel batasan waktu audit dan skpetisme profesional mampu menjelaskan terhadap variabel kualitas audit internal pemerintah dengan baik, dalam hal ini bahwa variabel independen yang diamati memiliki kontribusi yang besar pengaruhnya terhadap variabel dependen yaitu kualitas audit.

Dari temuan empiris menunjukan bahwa batasan waktu audit berpengaruh positif terhadap kualitas audit, yang artinya Auditor internal pemerintah sangat bergantung kepada batasan waktu yang tersedia guna melakukan sebuah pemeriksaan, sehingga dengan batasan waktu yang cukup lama akan membuat auditor internal dapat mengumpulkan bukti yang cukup dan kompeten sebagai pertimbangan dalam memberikan sebuah opini yang akan berdampak positif terhadap kualitas audit. Disisi lain apabila penetapan batasan waktu terlalu lama hal ini akan berdampak negatif pada tingginya biaya pelaksanaan audit.

Selanjutnya untuk variabel skeptisme dari hasil temuan empiris menunjukkan pengaruh positif terhadap kualitas audit, dengan ditemukannnya bukti bahwa peran dari sikap skeptis sangat dibutuhkan bagi seorang auditor internal pemerintah, sehingga dengan sikap skeptisme auditor tidak mudah percaya terhadap bukti yang diperolehnya, selain itu auditor harus tetap menjaga kualitas bukti audit yang diperolahnya sehingga auditor tidak sesat dalam memberikan sebuah opini.

\section{KETERBATASAN PENELITIAN}

Penelitian dilakukan hanya menggunakana instrumen penelitian dalam quesioner dengan pertanyaan tertutup, sehingga data yang diperoleh kemungkinan hasilnya bias dikarenakan tidak semua responden menjawab pertanyaan sesuai dengan keadaan yang melingkupinya, sehingga perlu butir-butir pertanyaan melalui wawancara untuk mengantisipasi jawaban yang dianggap netral. Dan Penelitian hanya dilakukan kepada responden yang bekerja di tempat dan lokasi kerja yang sama.

\section{SARAN}

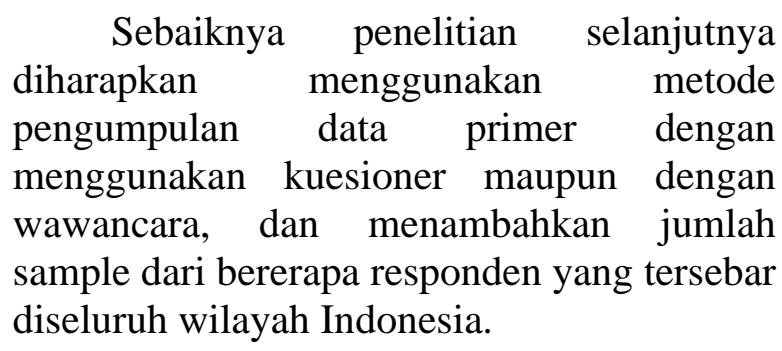

\section{DAFTAR PUSTAKA}

AAIPI. Standar Audit Intern Pemerintah Indonesia (2013). Jakarta.

Afriyani, N., Anugerah, R., \& Rofika, R. (2014). Pengaruh Kompetensi, Motivasi dan Skeptisme Profesional terhadap Kualitas Audit Auditor Inspektorat Seprovinsi Riau. Jurnal Online Mahasiswa Fakultas Ekonomi Universitas Riau, 1(2).

Anugerah, R., \& Akbar, S. H. (2014). Pengaruh Kompetensi, Kompleksitas Tugas dan Skeptisme Profesional terhadap Kualitas Audit. Jurnal Akuntansi, 2(2), 139-148. https://doi.org/10.1016/j.jaap.2015.03.0 07

Ardian, A. (2013). Pengaruh skeptisme profesional, etika, pengalaman, dan keahlian audit terhadap ketepatan pemberian opini oleh auditor. Jurnal Akuntansi, 1(3), 1-34.

Arens, A. A., Elder, R. J., Beasley, M. S., \& Hogan, C. E. (2017). Auditing and Assurance Services An Integrated Approach (16th ed.). Pearson.

Bachtiar, H. (2017). Pengaruh Due Profesional Care, Pengalaman Audit, Pendidikan Dan Pelatihan Berkelanjutan Terhadap Kualitas Audit Internal Dengan Komitmen Organisasi Sebagai Pemoderasi (Studi Pada Aparat 
Sumartono, MR Pasolo \& Kevin N, Studi Empiris Kualitas Audit Internal Pemerintah...

Pengawasan Internal Pemerintah Inspektorat Pemerintah Kota Lhoksemawe. Universitas Syiah Kuala.

Chandarin, G. (2018). Metode Riset Akuntansi Pendekatan Kuantitatif (Cetakan Ke). Jakarta: Salemba Empat.

Darmawati, D., \& Dewi, R. N. (2018). Peran Good Governance Terhadap Kualitas Audit Kepabeanan Di Indonesia. In Seminar Nasional Cendekiawan Ke-4 (pp. 939-945). Jakarta.

DeAngelo, L. E. (1981). Auditor size and audit quality. Journal of Accounting and Economics, 3(3), 183-199. https://doi.org/10.1016/01654101(81)90002-1

Efendy. (2010). Pengaruh Kompetensi, Independensi dan Motivasi auditor terhadap Kualitas Audit Inspektorat dalam Pengawasan Keuangan Daerah (Studi Empiris pada Pemerintah Kota Gorontalo). Universitas Dipenogoro.

Ghiselli, E. E., Campbell, J. P., \& Zedeck, S. (1981). Measurement Theory for the Behavioral Sciences. New York: W.H. Freeman and Company.

Ghozali, I. (2016). Aplikasi Analisis Multivariete dengan Program IBM SPSS 23 (8th ed.). Semarang: Badan Penerbit Universitas Diponegoro.

Giroux, G., \& Jones, R. (2011). Measuring audit quality of local governments in England and Wales. Research in Accounting Regulation, 23(1), 60-66. https://doi.org/10.1016/j.racreg.2011.03. 002

Hari, B. L., Rasuli, M., \& Darlis, E. (2015). Pengaruh Kompetensi, Independensi, Pengalaman Kerja, Kompleksitas Tugas Terhadap Kualitas Audit Aparat Inspektorat Dalam Pengawasan Keuangan Daerah Dan Reward Sebagai Variabel Moderating. Jurnal SOROT, 10(1), $1-18$ https://doi.org/10.13040/IJPSR.09758232.7(5).2015-19

Hartono, J. (2013). Metodologi Penelitian Bisnis: Salah Kaprah dan PengalamanPengalaman (6th ed.). Yogyakarta: BFEE UGM.
Hastuti, R. P. (2013). Kualitas Audit, Tekanan Waktu, Locus Of Control, Komitmen Profesional, Perilaku Penurunan Kualitas Audit. Universitas Gadjah Mada.

Indriantoro, N., \& Supomo, B. (2002). Metodologi Penelitian Bisnis untuk Akuntansi dan Manajemen (Pertama). Yogyakarta: BFEE UGM.

Kalau, A. A. (2013). Pengaruh Kompetensi, Independensi Dan Skeptisisme Profesional Auditor Internal Terhadap Kualitas Audit (Survey Persepsi Auditor Inspektorat Kota Ambon). Cita Ekonomika Jurnal Ekonomi, 7(2).

Koop, L., Lemon, M., \& Rennie, M. (2003). A Model of Trust and Professional Skeptisme in The Auditor-Client Relationship. In Presentation, School of Accountancy Seminar Series University of Waterloo (pp. 1-28).

Mardijuwono, A. W., \& Subianto, C. (2018). Independence, professionalism, professional skepticism. Asian Journal of Accounting Research, 3(1), 61-71. https://doi.org/10.1108/AJAR-06-20180009

Maulina, R., Darwanis, D., \& Saputra, M. (2017). Pennfaruh Batasan Waktu Audit, Pengetahuan Akuntansi, dan Auditing, serta Penglaman terhadap Kualitas Audit ( Studi Empiris Pada Inspektorat Provinsi Aceh ). Jurnal Magister Akuntansi Pascasarjana Universitas Syiah Kuala, 6(2), 59-64.

Messier, W. F., Glover, S. M., \& Prawitt, D. F. (2016). Auditing \& Assurance Services A Systematic Approach (10th ed.). New York: McGraw-Hill Education.

Mulyadi. (2014). Auditing (Ke Enam). Jakarta: Salemba Empat.

Nataline, N. (2007). Pengaruh Batasan Waktu Audit, Pengetahuan Akuntansi dan Auditing, Bonus dan Pengalaman Terhadap Kualitas Audit Pada Kantor Akuntan Publik di Semarang. Universitas Negeri Semarang.

Nunnally, J. C. (1967). Psychometric Theory. New York: US: McGraw-Hill. 
Journal of Business Administration Vol 3, No 2, September 2019, hlm, 245-257

Purwaningsih, S. (2018). Pengaruh Skeptisme Profesional, Batasan Waktu Audit, Kode Etik Profesi Akuntan Publik, dan Kompetensi Auditor terhadap Kualitas Audit (Studi Kasus pada Kantor Akuntan Publik di Tangerang dan Tangerang Selatan). Profita: Komunikasi Ilmiah Akuntansi Dan Perpajakan, 11(3), 513-535.

Rustiarini, N. W. (2013). Pengaruh Karakteristik Auditor, Opini Audit, Audit Tenure. Jurnal Ilmiah Akuntansi Dan Humanika, 2(2).

Sanjaya, A. (2017). Pengaruh Skeptisisme Profesional, Independensi, Kompetensi, Pelatihan Auditor, Dan Resiko Audit Terhadap Tanggung Jawab Auditor Dalam Mendeteksi Kecurangan. Jurnal Akuntansi Bisnis, 15(30), 144-158. https://doi.org/10.1177/2345678906292 430

Sugiyono. (2014). Metode Penelitian Kuantitatif, Kualitatif dan Kombinasi (Mixed Methods). Bandung: Albabeta.

Sumartono, S., \& Pasolo, M. R. (2019). The factors of financial report transparency in the regional government. Journal of Contemporary Accounting, 1(1), 11-25. https://doi.org/10.20885/jca.vol1.iss1.art 2

Suraida, I. (2005). Pengaruh Etika, Kompetensi, Pengalaman Audit dan Risiko Audit terhadap Skeptisisme Profesional Auditor dan Ketepatan Pemberian Opini Akuntan Publik. Sosiohumaniora, 7(3), 186-202.

Susilawati, \& Atmawinata, M. R. (2014). Pengaruh Profesionalisme Dan Independensi Auditor Internal Terhadap Kualitas Audit: Studi Pada Inspektorat Propinsi Jawa Barat. Jurnal Etikonomi, 13(2), 190-210. https://doi.org/10.15408/etk.v13i2.1886

Svanström, T. (2016). Time Pressure, Training Activities and Dysfunctional Auditor Behaviour: Evidence from Small Audit Firms. International Journal of Auditing, 20(1), 42-51. https://doi.org/10.1111/ijau.12054

Syarif, A. (2017). Pengaruh Batasan Waktu
Audit dan Kompetensi terhadap Kualitas Hasil Audit Pemerintah (Studi Empiris Kantor Perwakilan BPKP Provinsi Sumatera Selatan). Universitas Andalas.

Taman, A., Putra, A. W., \& Rachmawati, E. (2018). Kualitas Audit Auditor Internal Pemerintah : Kompetensi, Independensi, dan Profesionalisme. Jurnal Akuntansi, Ekonomi Dan Manajemen Bisnis, 6(1), 74-83.

Turangan, F. M., Saerang, D. P. E., \& Sondakh, J. J. (2016). Pengaruh Skeptisme Profesional, Kompetensi, dan Independensi Auditor terhadap Kualitas Pemeriksaan dalam Pengawasan Keuangan Daerah dengan Kepatuhan pada Kode Etik Sebagai Variabel Moderating. Jurnal Riset Akuntansi Dan Auditing “Goodwill," 7(2), 71-88.

Wijayanto, P. A., \& Mustikawati, I. R. (2017). Pengaruh Kompetensi, Independensi, Profesionalisme Auditor Internal Pemerintah Terhadap Kualitas Audit. Jurnal Profita: Kajian Ilmu Akuntansi, 8, 1-14.

Wiratama, W. J. (2015). Pengaruh Independensi, Pengalaman Kerja, Due Professional Care Dan Akuntabilitas Terhadap Kualitas Audit. E-Jurnal Akuntansi Universitas Udayana, 10(1), 91-107.

Yulia, Hasan, A., \& Hardi. (2016). Pengaruh Kompetensi, Independensi, dan Pengalaman Terhadap Kualitas Audit dengan Due Profesional Care Sebagai Variabel Interveing Pada Inspektorat di Kabupaten Siak dan Kuantan Singingi. Jurnal Ekonomi, 24(3), 168-183. 
Sumartono, MR Pasolo \& Kevin N, Studi Empiris Kualitas Audit Internal Pemerintah...

\section{LAMPIRAN}

\section{Kuesioner Penelitian}

Bagian 1 : Karakteristik Responden

Nama * ( Boleh tidak diisi)

Umur

20 - 25 Tahun

26 - 30 Tahun

$31-35$ Tahun

$>35$ Tahun

Jenis Kelamin

Laki-laki

- Perempuan

Lama Bekerja

0 - 5 Tahun

6 - 10 Tahun

11- 15 Tahun

$>15$ Tahun

Jabatan

Anggota Tim

Ketua Tim

Pengendali Teknis

Koordinator Pengawas

Tingkat Pendidikan

Diploma/DIII

S1

S2

S3

Bagian 2 : Skala Likert

\begin{tabular}{lllll}
\hline 1 & 2 & 3 & 4 & 5 \\
\hline $\begin{array}{l}\text { Sangat } \\
\text { tidak }\end{array}$ & $\begin{array}{l}\text { Tidak } \\
\text { setuju }\end{array}$ & $\begin{array}{l}\text { Ragu- } \\
\text { ragu }\end{array}$ & Setuju & $\begin{array}{l}\text { Tidak } \\
\text { setuju }\end{array}$
\end{tabular}

setuju

Skala di atas menunjukkan bagaimana Anda menjawab dengan setuju/ tidak setuju melalui item-item pernyataan di bawah ini:

\section{Kualitas Audit Internal Pemerintah}

\section{Item}

1. Saat menerima penugasan, auditor menetapkan sasaran, ruang lingkup, dan metodologi pemeriksaan

2. Semua pekerjaan saya harus direviu oleh atasan secara berjenjang sebelum laporan hasil pemeriksaan dibuat.

3. Proses pengumpulan dan pengujian bukti harus dilakukan dengan maksimal untuk mendukung kesimpulan, temuan audit serta rekomendasi yang terkait.

4. Auditor menatausahakan dokumen audit dalam bentuk kertas kerja audit dan disimpan dengan baik agar dapat secara efektif diambil, dirujuk dan dianalisis

5. Dalam melaksanakan pemeriksaan, auditor harus mematuhi kode etik yang ditetapkan

6. Laporan hasil pemeriksaan memuat temuan dan simpulan hasil pemeriksaan secara obyektif,serta rekomendasi yang konstruktif

7. Laporan mengungkapkan hal-hal yang merupakan masalah yang belum dapat diselesaikan sampai berakhirnya pemeriksaan

8. Laporan harus dapat mengemukakan pengakuan atas suatu prestasi keberhasilan atau suatu tindakan perbaikan yang telah dilaksanakan pada obyek pemeriksaan
9. Laporan harus mengemukakan penjelasan atau tanggapan pejabat/pihak obyek pemeriksaan tentang hasil pemeriksaan

10. Laporan yang dihasilkan harus akurat, lengkap,obyektif, meyakinkan, jelas, ringkas,serta tepat waktu agar informasi yang diberikan bermanfaat secara maksimal

\section{. Batasan Waktu Audit}

\section{Item}

1. Saya membutuhkan waktu lebih banyak untuk menyelesaikan tugas yang sama dibanding auditor lain

2. Saya terbiasa menyelesaikan pekerjaan sesuai dengan batas waktu yang ditentukan

3. Saya memandang batas waktu dalam penugasan audit sebagai beban

4. Saya melakukan reviu secara sepintas terhadap dokumen klien

5. Bila batas waktu audit terlalu ketat, mendorong saya untuk menghilangkan pekerjaan yang tidak perlu dalam penugasan

6. Bila batas waktu audit terlalu ketat, mendorong saya untuk lebih memusatkan perhatian dalam penyelesaian pekerjaan audit

7. Dengan tingkat pengalaman yang saya miliki, saya dapat menyelesaikan tugas audit lebih cepat dibanding auditor lain

8. Pengetatan batas waktu audit mengganggu pekerjaan audit saya

9. Kepatuhan terhadap prosedur audit biasanya menurun jika batas waktu yang ditetapkan terlalu sempit

\section{Skeptisme Profesional}

\section{Item}

1. Kepercayaan diri yang tinggi harus saya miliki dalam melaksanakan audit

2. Menerapkan sikap skeptisme profesional dengan tidak cepat puas dengan bukti audit yang ada

3. Skeptisme profesional auditor mencakup pikiran yang selalu mempertanyakan dan melakukan evaluasi secara kritis terhadap bukti audit

4. Skeptisme profesional yang dimiliki, diperlukan terutama saat memperoleh dan mengevaluasi bukti audit

5. Auditor tidak boleh mengasumsikan begitu saja bahwa manajemen adalah tidak jujur, tetapi saya juga tidak boleh mengasumsikan bahwa manajemen sepenuhnya jujur

6. Memiliki kemahiran profesional yang cermat dalam mengaudit laporan keuangan

7. Sepenuhnya melaksanakan audit dengan menganggap bahwa ada kemungkinan terjadinya salah saji dalam laporan keuangan

8. Membuat penaksiran yang kritis terhadap validitas bukti audit yang diperoleh

9. Waspada terhadap bukti audit yang bersifat kontradiksi 